\title{
THE COLONIAL BIRDS AT SUGGI LAKE, SASKATCHEWAN, IN 1966
}

\author{
by Richard M. Sanderson, Molanosa, Sask.
}

In the last issue of the Blue Jay (June, 1966) there appeared a letter entitled "Destruction of colonial birds on an island on Suggi Lake", by Ralph Carson, which showed a considerable disturbance of pelicans and cormorants in 1964, and which advocated research into the status and protection being afforded these birds. After reading this I decided to visit the colony. On June 29, 1966, I flew from Deschambault Lake, 90 miles northwest of Suggi Lake, to the island which lies in the middle of Suggi Lake. "Suggi", according to my informants, is a Cree Indian word meaning "hurry-up".

The results of the 90 minutes I was able to spend on the island, and the subsequent information I have obtained, indicate that the colonies have undergone some destruction with the apparent loss of Double-crested Cormorants and Great Blue Herons as breeding species for at least this year. As well, it would appear that the degree of loss suffered by these and other species nesting on the island varies from year to year.

The island is the westernmost of two long, narrow islands situated slightly southwest of centre on the lake. It is approximately threequarters of a mile long, less than 100 feet wide, and is about 15 feet above the lake level. Only the northern half of the island, as shown by Carson, is suitable nesting habitat for colonial birds, the rest being a tangle of fallen trees and weeds, with some mature poplar, spruce, and assorted bushes at the south end of the island. The predominant ground cover around the open patches on the northern half of the island is stinging nettles and small weeds. The nettles were three feet high while the rest of the weeds were no more than six inches high. The northernmost tip of the island is a jumble of boulders devoid of vegeta- tion and not occupied by any of the colonial species. The shoreline is steep and rocky.

Each spring, from about the last week of May until the middle of June, a native commercial fishing crew fishes for pickerel and whitefish at the lake. The length of time which they spend at the lake depends upon the time it takes them to catch their yearly limit. The natives come to Suggi Lake from the Cumberland House area via the North Saskatchewan and Grassberry rivers. In 1966, fishing operations took about two weeks and ended about the second week in June, according to Bob Heidel, Nipawin Air Services, the pilot who flew the fresh fish out to a processing plant at Jan Lake. Mr. Heidel also said that the fishermen were camping on the island next to the one on which the birds were nesting. A small shed on the adjacent island is used to store the fresh fish until the aircraft arrives. Heidel believed that the birds were being protected by a conservation officer from Cumberland House.

I made a hasty survey beginning at the middle of the island and working in a northerly direction, recording nests, eggs, young, etc. The suitable half of the island is divided into specific breeding areas. The first nest area encountered was a deserted White Pelican colony. There were 213 deserted nests with approximately 250 destroyed eggs lying about, some in the nests and others scattered throughout the area. Crushed eggs made an accurate count impossible. All of the eggs not crushed appeared to have been broken open and eaten by gulls; these eggs had a characteristic jagged hole in the side and were entirely cleaned out. One egg which was not broken was found to be rotten and had no embryological development. The next colony was that of Common Terns. Some were nesting on top of 


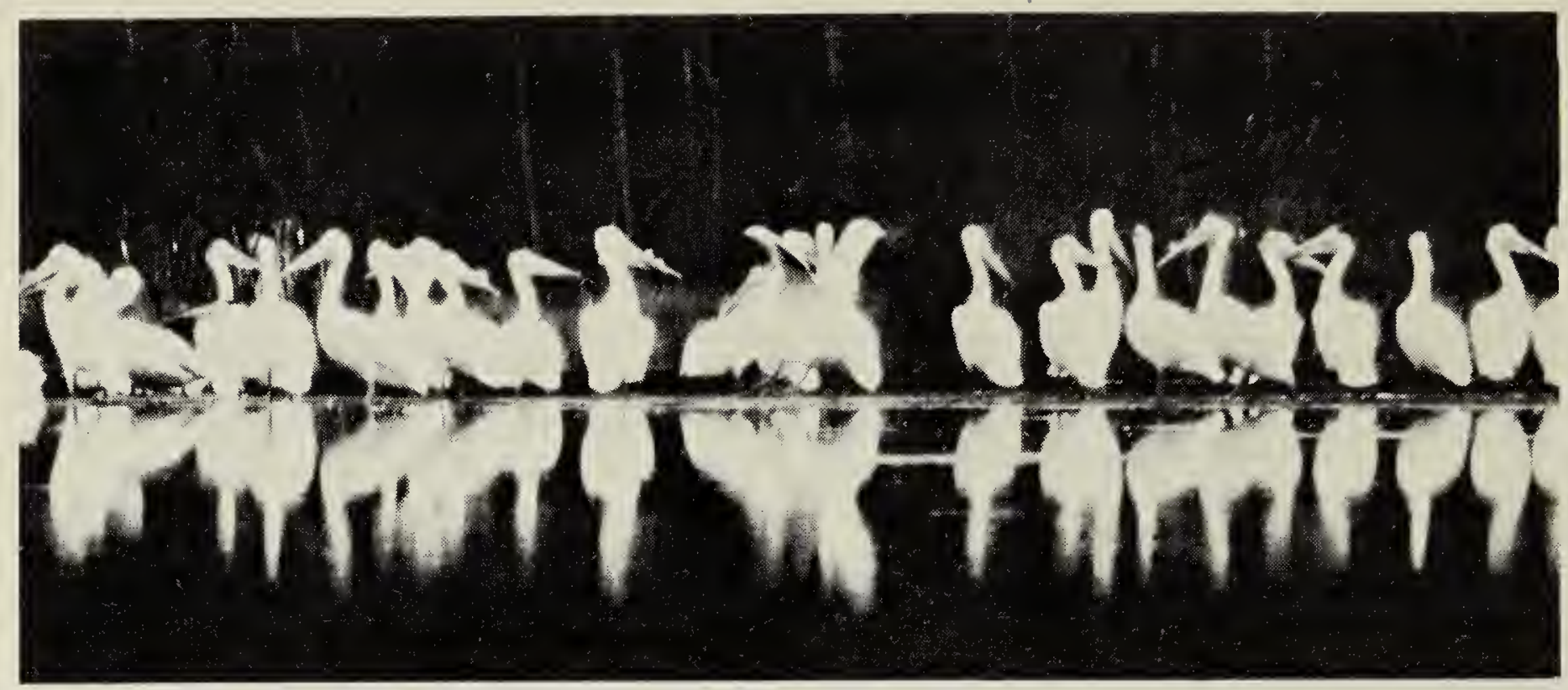

The White Pelican

Photo by Doug Gilroy

the deserted pelican nests at the edge of the deserted colony. I counted 347 Common Tern nests, and undoubtedly overlooked some which were hidden in the nettles and other weeds at the edge of the open patches. There were 724 eggs and 61 young. The largest. young, I judged to be about a week and a half old. The next colony was the first of two adjacent Ring-billed Gull colonies separated by a heavy growth of nettles. Carson, in 1964, and Fox, in 1959, reported large colonies of California Gulls, but all that I could identify were Ring-billed Gulls. Some of the gulls were nesting on the rocky edge of the island which, in some places, rises slightly above the rest of the island. Once again, as with the terns, I undoubtedly failed to record some nests and young because of the heavy weed growth which had, in some cases, formed a canopy over the nests. I recorded 237 nests with a total of 387 eggs; 261 young were still in the nests, plus 510 young running loose in singles or more commonly in bunches. As well, 72 eggs were lying at random on the ground. These are combined figures for both colonies.

The next colony was that of the pelicans - an attempt at renesting. Here I found 121 nests with $2 \ddot{z} 2$ eggs. There were 41 nests with one egg each, 59 nests with two eggs each, and 21 nests with three eggs each. Approximately 500 adult pelicans were counted swimming one-quarter mile offshore. There were no young. The pelicans had flattened several square yards of nettles in order to make room for themselves but none were nesting on the nettles. It would appear that the pelicans successfully renested at the north end of the island after a failure at the middle of the island. They did not, however, nest in as large a number. Carson found about 300 nests in 1964 and observed that the major part of the nesting habitat had been occupied by pelicans prior to their desertion.

Immediately behind the pelican colony was a loose colony of Herring Gulls. They were nesting among rocks along the east edge of the island. As well, there was the odd nest near the Ring-billed Gull colonies, but none near the tern colony. Nine nests were found with 14 eggs and six young. There were some young Herring Gulls running about on the island with the other gulls. The largest young Herring Gull, I judged at about three weeks old.

I found no cormorant nests nor did I see any adult birds. There were four old Great Blue Heron nests but no adults were seen. Most of the trees suitable for heron nests had fallen to the ground.

It is my belief that the pelicans, being particularly vulnerable to egg stealing by gulls, are disturbed every year that commercial fishing operations are carried out on Suggi Lake. 
While wanton destruction has occurred, I believe it is the noise of the fishing boats constantly roaring past for two weeks that contributes most to the initial desertion. The fishing crews do not usually remain in the area after fishing operations have ceased, which is usually about the third week of June. It is at this time that the pelicans can re-nest, as they have done this year. It is quite likely that some fishermen did visit the island to gather eggs to eat, for this is a common practice all over northern Saskatchewan. I found no campfires on the island and no bird carcasses. I assume that the gulls and terns began laying eggs before the arrival of the fishermen, and had incubated them to a point where few were taken for food by the natives. Once a plainly visible embryo is formed most natives will not collect the eggs for eating purposes. The pelicans probably had a head start also, but the continuous activity may have disturbed them off their nests long enough and often enough to allow the many gulls to swoop in and rob most of the eggs.

I estimated that there were present on the island 1500 gulls, 500 pelicans, and 1000 common terns (all adults). Other species seen on or near the island were: Three male White-winged Scoters, one Franklin's Gull and one Spotted Sandpiper with a nest (four eggs) .

I see no way to avoid disturbing the pelicans so long as the fishing operations base remains on the adjacent island, which, as far as fishing is concerned, is an ideal location for the camp. On the other hand the pelicans must be afforded the full protection of the law. Periodic checks of the pelican colony after the fishing operation is completed should be made to determine nesting or renesting success. If it is found that the delay in nesting caused by fishing activity disturbances does not allow sufficient time for the successful rearing of young pelicans and if relocation of the fishing camp is not feasible, then other solutions to the conflict between the colonial birds and fishing interests should be considered.

\section{NEED FOR \\ PELICAN PROTECTION}

by C. Stuart Houston

836 University Drive, Saskatoon

Because of Ralph Carson's note "Destruction of colonial birds on an island on Suggi Lake," Blue Jay XXIV, p. 96-97, June 1966, I am adding the following notes some of which were published in Audubon Field Notes 18:515, October, 1964. On July 1, 1964 my wife and I chartered a plane from Nipawin to Suggi Lake. This was just 15 days afer Carson's trip which was reported in the last Blue Jay. On the long narrow rocky islet there were 466 White Pelican nests, 462 with eggs and the remainder with newly hatched young less than two days old. There were 53 Doublecrested Cormorant nests, all with eggs.

Our pilot, Ed Leclair, told us that Indians had been fishing commercially on this lake from May 13 to May 30. Presumably all original nests on the island were destroyed at that time and the birds had renested. By July 1 the young of the year should have been old enough to band so I wondered if the young would mature sufficiently to be able to make the fall migration.

I agree with Ralph Carson concerning the need for protecting the White Pelican before it is too late. The fishing operations of Suggi Lake is a relatively recent development which could soon sadly reduce the pelican population there. The White Pelican population is threatened elsewhere in Saskatchewan too. At Redberry Lake mid-day visits from increasing numbers of boaters who do not know that a short exposure to direct sun may kill a young pelican, threatens the pelicans though the Canadian Wildlife Service signs seem to have helped a lot. On Old Wives Lake the decreasing size of the pelican colony may be related to the use of toxic chemicals on farmlands draining into one of their main feeding areas-Thompson Lake. 